\title{
Have you ever been in Bosnia?: British military travelers in the Balkans since 1992
}

\begin{abstract}
:
Tens of thousands of British military personnel traveled in former Yugoslavia as peacekeepers between 1992 and 2007. The settlements where British forces established their military presence and supply chain were conceptually far from former Yugoslavia's tourist sites, but military travelers made sense of them by drawing on the commonplaces of previous travel accounts and the lessons of pre-deployment training.
\end{abstract}

British military travelers constructed themselves as often frustrated helpers in Bosnia who struggled with political limitations on their activities but found satisfaction in improving socio-economic relations at the level of the immediate community. For troops, long otiose periods in a stabilizing and startlingly cheap country engendered a touristic sensibility. This paper draws on published memoirs and more than fifty new oral history interviews with British peacekeepers and their Bosnian employees to illustrate how British military travelers drew on, perpetuated and changed the patterns and representation of British travel to the Balkans.

Keywords: peacekeeping, military, Bosnia-Herzegovina, Balkans, travel

Word count: 10,000 
Since 1992, when the United Nations Protection Force (UNPROFOR) entered Croatia, tens of thousands of British military men and women have traveled to former Yugoslavia. The troop contribution that began with one field ambulance and several military observers in Croatia became dozens of infantry and cavalry battalions, combat support regiments, logistics units, headquarters establishments and individual postings as the UK became one of the multinational force's lead nations in 'the Balkans'. British troops served in BosniaHerzegovina (BiH) until 2007, implementing and monitoring the Dayton Peace Agreement and experiencing the changeover from UNPROFOR to its NATO replacements, IFOR (Implementation Force) and SFOR (Stabilization Force). Another force gathered in Macedonia in 1999 before entering Kosovo. During the 2000s, British forces gradually handed over their responsibilities in former Yugoslavia to European Union and NATO allies. However, in the confusing decade between the end of the Cold War and the origins of the War on Terror, Britain's most significant operational deployment was to this very region.

The sudden growth in published travel accounts of south-east Europe and its crisis zones during and since the 1990s has led scholars to analyze representations of 'the Balkans' in journalism, literature and film, narratives very often framed as accounts of real and imagined travel by a westerner. The most recent research on travel writing and the Balkans has also opened the dimension of European travel by south-east Europeans themselves (Bracewell and Drace-Francis ed. 2008). A focus on published travel writing, however, restricts the field to the small number of travelers who submit their work for publication. For instance, the British officers' autobiographical narratives in Claire Duncanson's article on peacekeepers' constructions of masculinity are three books and one article in a strategic studies journal (Duncanson 2009). Other memoirs published between 1993 and 2010 include those of battalion commanders (Stewart 1993; Barry 2008), one battalion's composite memoir (Royal Welch Fusiliers 1995), a fictionalized SAS account from Goražde (Spence 1999), and a study 
of military liaison partly drawing on the author's own experience as a British liaison officer in 1995 (Chalmers 2001). There are strong grounds also to consider the memoir by the photojournalist Anthony Loyd (1999) quasi-military as well journalistic: the troubled narrator served in the Royal Green Jackets before traveling to $\mathrm{BiH}$ and from the outset interpellates the reader as a person able to recognize and sympathize with a professional military subjectivity.

This paper draws on oral history interviews with fourteen British military personnel, collected by the author among fifty-one interviews for a research project into foreign languages and peacekeeping, ${ }^{1}$ supplemented by further oral histories collected by others and stored at the Imperial War Museum (IWM) sound archive and by the corpus of published memoirs above. It seeks to compare the experiences of personnel whose missions compelled them to make sense of BiH's politics, culture and language while staying for six months or more: negotiation and consent, so important to the peacekeeping concept, made almost all military tasks intercultural, interlingual encounters; as Robert Rubinstein (2008: 90) writes, 'the essence of peacekeeping is in the many individual actions taking place each day between peacekeepers and the people they are deployed to help'. The participants range from military interpreters and language instructors to forward air markers and Royal Electrical and Mechanical Engineers (REME). Their narratives span many locations, duties, objectives and political phases but share common features of travel encounters: a pre-deployment familiarization phase, arrival in $\mathrm{BiH}$ through a neighboring country, the experience of work, the experience of leisure and the journey home. Oral history is as vulnerable as memoir, perhaps even more so, to exaggeration, self-effacement, concealment and unconscious processes of forgetting, making it a problematic but fascinating resource for research about the past. ${ }^{2}$ Both sets of military travel accounts discussed in this paper, the published and the recorded, conform to the conventions of travel narrative. The circumstances of their 
production, on the other hand, diverge: whereas published works emerge from creative and commercial negotiations with editors, agents and others, ${ }^{3}$ in oral history the researcher and interviewer performs the work of mediation.

Analyzing these military narratives presents the same problem faced by, for instance, Jean and John Comaroff (1991) in their study of Nonconformist missionaries in the colonization of South Africa: the rationale for the travel and presence of the texts' authors was based on individually deeply-felt values and convictions yet was implicated within a wider scheme of unequal global power relations. Indeed, should one follow Stef Jansen (2006: 190) in critically conceiving of international organizations' work in $\mathrm{BiH}$ as a project to remake a consciousness based on privatized capitalism after the fall of socialism, the comparison would develop a further layer. A case such as $\mathrm{BiH}$ throws up a further ethical difficulty in that the authors of narratives are still alive and, in the case of accounts personally collected by the author, that they contributed their narratives in sympathy with the overall aims of the project (to research the impact of languages on peace operations in $\mathrm{BiH}$ ). How, then, to reconcile what are often accounts of individual achievement and learning with what may be a far less rosy structural perspective? Historicizing narratives of travel and movement requires the historian to take into account their role in constructing a certain form of knowledge and ultimately in supporting certain orders of relations that have practical effects on people's and peoples' political and economic power (Pratt 1985). Military travelers had privilege not only in their foreignness - endowing them with hard currency, the ability to leave, and the comfort of a secure home abroad - but in their equipment, their training, and their legalized power to defend themselves by force. The Comaroffs come to describe their own field of study not as 'a simple exercise in domination and resistance' but as 'a dialectic, mediated by social differences and cultural distinctions [...] founded on an intricate mix of visible and invisible agency' (Comaroff and Comaroff 1997: 28). The efforts to engage, understand, withdraw or 
reject that appear in the narratives below were slices of this dialectic, moments of benefit, detriment or both within a structural context that even some of its participants have come to doubt.

\section{Making sense of Bosnia}

'Bosnia' was a little-known country to most foreign soldiers, unless they could make sense of it within the 'Balkans' frame (as the post-Yugoslav conflict flowed from Croatia through BiH to Kosovo) or relate it to peacetime travel: Sarajevo had hosted the 1984 Winter Olympics and Bosnia was near holiday destinations in Croatia. Several British interview participants introduced the Croatian coast while situating the region in their narratives. 'People used to go on holiday to Yugoslavia before the war,' said Louise, a Royal Army Educational Corps captain and military interpreter who served in 1993-94. 'It was what people did, a beautiful country. ${ }^{44}$ Eric, an Intelligence Corps reservist trained in Serbo-Croat in order to join a UKbased team debriefing refugees in 1992-93, contrasted the resort to the war zone while describing his language course: 'the vocabulary was very much geared, not to your holidays in Dubrovnik, but very much to what was happening in Banja Luka. ${ }^{5}$ The language (fast becoming the languages) of $\mathrm{BiH}$ was even more inaccessible to most military travelers, with the exception of soldiers and officers who volunteered for crash courses organized by the Defence School of Languages (DSL) at Beaconsfield. Serbo-Croat, like all other east European languages, had taken a distant back seat to Russian in UK higher education, meaning that the Army contained only one graduate speaker and three heritage speakers when the Yugoslav conflict began.

Research into western representations of 'the Balkans' was inspired by and has developed since the aftermath of these very conflicts - beginning with the work of Milica Bakić-Hayden 
and Robert Hayden on equivalents of Orientalism in Yugoslav political discourse (BakićHayden and Hayden 1992) and Maria Todorova's reminder that the very term 'the Balkans conflict' was a misnomer because it only involved successor states of Yugoslavia (Todorova 1997). The travel writing scholar Andrew Hammond has argued that, from the 19th century onwards, Anglo-American travelers to the Balkans adopted a cynical and denigratory gaze that made foreign rule appear indispensable (Hammond 2007: 247). Hammond suggests that later authors were able to emulate imperial Victorian travelers by testing their 'heroism and endurance' in the Balkans, and that in the 1990s the mode of chaotic and violent representation was transferred from the Yugoslav wars to post-Communist social crises in other Balkan countries (Hammond 2007: 234, 267). The paradigmatic British military traveler to the Balkans in the 20th century was the Special Operations Executive agent Fitzroy Maclean, whose memoir Eastern Approaches was reissued by Penguin in 1991 when the Yugoslav crisis first came to international attention. Hammond's reading of Maclean implies that the Balkans were of significance to him primarily as an arena where the military traveler could hone masculine virtues (just as passage through the South African landscape served primarily to the Comaroffs' missionaries as a site of self-transformation (Comaroff and Comaroff 1991: 174)):

what Maclean is commending [in a description of shaving with snowmelt and a mess-tin] are the positive qualities that he feels the region has nurtured in himself: namely, competence, simplicity, masculinist flair and active participation in 'gallant struggle' and 'comradeship', a typical combination in these wartime texts. (Hammond 2007: 202). 
The Army as an institution was still keen to draw on Maclean's knowledge in 1992, when he was flown to Zagreb to brief a British reconnaissance party before it entered $\mathrm{BiH}^{6}$

In the 1990s, British public knowledge about Yugoslavia was disseminated through television news and through several categories of book: reportage; new histories by academics, journalists and diplomats; translated fiction that reshaped the canon of Yugoslav literature for an audience seeking the origins of what it supposed to be a deep-rooted ethnoreligious conflict; and 'classic' accounts of travel to the Balkans often republished by opportunistic publishers. Ivo Andrić's historical novels, depicting struggles between Muslim state officials and Christian townspeople in Ottoman Bosnia, appeared as high-street paperbacks and provided first experiences of Yugoslav literature for many interested Britons (this author included). Equally important literary works, such as Miroslav Krleža's novels about the Croatian middle classes between the World Wars, remained in limited print runs or untranslated. The historian Brendan Simms (2002: 179-80) argues that familiarity with one 'rabidly Serbophile travelogue', Rebecca West's Black Lamb and Grey Falcon, combined with 'half-remembered military history' of Serbs' part in the Second World War to predispose British officers to an 'instinctive professional fraternalism' with Bosnian Serbs. The generalization cannot be applied to all British personnel, whose reactions could range from sympathy with a side they perceived as the underdog or victim to a cynical moral equivalence equally antipathetic to all parties in the conflict. It nonetheless shows that travel writing and popular memory of history may both have a direct impact on soldiers' understandings of conflicts and of the regions to which they travel.

While British diplomacy's early-1990s sanctions policy most disadvantaged Bosniaks/Bosnian Muslims and the Sarajevo government, public sympathies lay with that very side based on a huge volume of media reports between the discovery of the Omarska concentration camp in 1992 and the fall of Srebrenica in 1995. Troops, however, had to serve 
in territory controlled by Serbs, Bosniaks and Croats and win all three populations' trust, according to the 'hearts and minds' theory already structuring overseas military operations. Indeed, after Dayton, the new British area of responsibility (AOR) was designed to include land straddling the Inter-Entity Boundary Line between BiH's two constituent entities, the Federation and the Republika Srpska. Tony French, an artillery officer whose regiment joined one such post-Dayton deployment, was tasked with briefing his enlisted soldiers on Bosnian history and culture. With guidance from the Army training team, Tony chose to instill an ethic of impartiality and counteract any sympathies troops might have built up as members of the public. He compared the situation to Northern Ireland, where the regiment had previously expected to go:

So actually, it's a bit like Northern Ireland. We're not saying that, you know, the Catholics are bad, and - I'm a Catholic, for instance - but, you know, Catholics are bad and Protestants are good. Definitely not that. You spend most of your time trying to give a balanced view, because sometimes we have to sit on the fence, and it's very hard if you start giving those little nuances to soldiers. They can, particularly when they're by themselves, they could do something not too good. $^{7}$

Interpreting $\mathrm{BiH}$ through the lens of Northern Ireland, however, had its risks in wartime. Brendan Simms's argument that Britain should have taken a far stronger moral stand in BiH sees Northern Ireland as an 'unfortunate analogy' that led officers to value equivalence and separation from the HQ UNPROFOR level downwards, to the dismay of the US general Wesley Clark: 'when they transposed that into Bosnian terms what happened, at least over a period of time, was the UN didn't want to take sides' (Clark in Simms 2002: 181). 
Pre-deployment training always included some historical and cultural content such as the briefing discussed above; its main focus, however, was preparing soldiers for military tasks through 'special-to-theatre' training, developed through regular feedback from trainers who had been serving in BiH. During Operational Training Group (OPTAG) exercises at mock villages in the UK or Germany, soldiers practiced rules of engagement, role-played situations at uncooperative local checkpoints, rehearsed evacuation drills and learned procedures should they encounter unexploded mines. A 'use of interpreters' module delivered by DSL was quickly included following feedback that the first Britons carefully trained to speak 'SerboCroat' had been under-used because their superiors had had unrealistic expectations of their skills. Native speakers of the local language - DSL's civilian language instructors, Bosnian refugees hired by the day and local interpreters flown in from $\mathrm{BiH}$ itself - played civilians and improvised scenarios within the trainers' general script. Ben Barry's recollection of his battalion's training as 'astonishingly realistic' (Barry 2008: 56) is a typical OPTAG memory - suggesting, at least, that nothing they encountered or remembered in $\mathrm{BiH}$ had made them doubt the content of the package, though showing no sign that training had encouraged reflexivity or (as Robert Rubinstein (2008: 12) warns of the 'travelers advice' training model) challenges to the concept of one's own and others' culture as fixed and static.

In the work of readying the personal and collective self for new conditions, cultural and linguistic training was only one element, and preoccupied soldiers no more (or much less) than the practical aspects of preparing to deploy: acquiring kit, 'special-to-arms' weapons training, learning the rules of engagement and anticipating the likely climate. Geoffrey, a reservist who volunteered for full-time service in late 1995 and was posted to IFOR HQ at the Ilidža hotel complex in Sarajevo, recalled that his induction: 
involved medical tests, dental tests, inoculations, being equipped, and certain elements of training, like firing, zeroing weapons, and becoming more used to some weapons which one wouldn't otherwise perhaps be armed with, for example, the pistol. And waiting, really, for clothing and equipment to arrive [...] although I was given various items of kit which I never used. I mean, an Arctic-weight pair of gloves, for example, and a face mask to keep the cold out. Obviously, living in a hotel as I did, that wasn't the sort of thing I needed. ${ }^{8}$

\section{Entering theatre}

The first actual British military travel to BiH since SOE missions during the Second World War (besides short visits defense attachés are likely to have made during Tito’s Yugoslavia) was a UK Land Forces reconnaissance mission in August 1992 in preparation for contributing an armored infantry battalion to UNPROFOR. The party, including the only British officer (a captain) with a degree in Serbo-Croat, initially flew to Belgrade and tried to enter eastern Bosnia but were turned back before Zvornik, a border town where Serb paramilitaries were massacring non-Serb residents. A week later, entering central Bosnia through Herzegovina, the party established the major sites of the British presence in BiH until Dayton: a battalion base at Vitez, company bases in Gornji Vakuf and Tuzla, a logistics base in Tomislavgrad and the rear brigade headquarters inside Divulje Barracks, a complex in Split rented from the Croatian Army. Divulje Barracks was quickly nicknamed 'Slipper City' after another comfortable rear base in Northern Ireland, as Louise explained:

[when] people were indoors they wouldn't wear their stout leather army boots, but they would wear desert, you know, can't remember what they're called, we 
called them desert wellies but do you know what I mean?, little sandy-coloured suede comfortable shoes, hence Slipper City, and people based at HQ and Slipper City were always frowned upon by those at the sharp end. ${ }^{9}$

Narratives of transit through Split often included uncomfortable flights in Hercules aircraft and hassles with Croatian border police, but also the experience of staying temporarily in an attractive city oriented towards tourism. Geoffrey, for instance, constructed it as a location of coastal beauty with historical precedents for military leisure: the nearby town of Trogir was 'actually an architectural gem, if that is your bag, with so much marble it's all over the pavements', where a French officer had ordered a leisure islet built during the Napoleonic Wars (suggesting a certain continuity between the British peacekeeping presence and the full French occupation of the Adriatic coast). ${ }^{10}$ The barracks itself contained many bars operated by different British regiments, including the Royal Engineers' bar, the setting for anecdotes told by both Louise and George (a REME lieutenant in 1998). For Louise, the 'Rorke's Drift' bar (commemorating an Engineer lieutenant who commanded the defense of Rorke's Drift; the name inscribed the mythic battle of colonial warfare into the 1990s Balkans) had been the site for an encounter that exposed the distance between the British military culture of irreverent humor and local Croatian norms of patriotism. A Croatian flag on display above the bar turned out to have been stolen and a visibly emotional Croatian liaison officer demanded its return:

I said [to the Engineer who had taken the flag], 'OK, flag, Rorke's Drift bar, did you steal it? (laughs)' 'Well, yeah, you know (laughs) soldiers do, soldiers take flags.' 'OK, go and get it right now.' So he went and got it, brought it back, Stefan [the Croatian officer] was crying and trembling. And he took the flag like 
a newborn baby, and he folded it in a very special way that only someone who knows about their national flag can fold, and it ended up in a nice little packet, a triangle, and took it away. And we got away with it. ${ }^{11}$

By the time of George's tour in BiH six years later, dozens of units (thousands of troops) had established leisure routines taking in the diversions of 'DJ Barracks' as well as the Army's official adventurous training centre on the Croatian island of Brač: indeed, he remembered '[y]ou'd try and get down to Divulje Barracks, in Split, because there was a bit of a holiday camp. ${ }^{12}$ His own Engineers' bar story (remembering the forfeits and 'booby-traps' that had made the bar popular among soldiers from all units) placed the base's relationship with the local population into the background, foregrounding nuances of regimental identity that structured the meaning of belonging to the British Army.

British soldiers departed from Split along the Main Supply Route and experienced the transition from coastal resort to remote mountainous conflict zone, witnessing the remains of the built environment in the countryside and the constant threat of Bosnia's dangerous roads and drivers. A diarist in Ben Barry's battalion was typical of memoirists and interviewees alike in his comments on Bosnian roads:

Bosnian driving provided amusement, and often danger. If there is a Bosnian Highway Code, then it is almost a reverse of the British one. In Bosnia it would seem to be mandatory to overtake on blind corners, especially if driving a packed coach on icy roads at night. (Barry 2008: 70)

Using the roads - or the skies, where apocryphally hard-drinking Czech pilots offered helicopter rides Britons did best to turn down - confirmed one's departure from the 
predictable safety of the rear into the operational space of uncertainty, violence and threat. The last stage of the journey into theatre, entering the small and remote Bosnian garrison towns for the first time, then carried overtones of forcing one's way into new territory: forward bases were sometimes described as located 'up country' and one interviewee referred to the small hamlets in his unit's AOR as 'remote village[s], where they hadn't seen any Europeans for years'. Entry-into-theatre transport narratives such as the diary quoted by Barry problematically attributed danger to an inherent quality of the Bosnian drivers rather than, for instance, the extreme weather, the condition of the vehicles or the impact of the war and lack of governance on the capacity to maintain roads and signage. Such 'manners-andcustoms' description, writes Mary Louise Pratt (1985: 139-40), tends to serve as a 'normalizing force' reifying and stabilizing the reality and ideology taken by the author to go without saying: in this case, the impression that the (essentialized) Bosnian subjectivity is thrill-seeking, amusement-worthy and even 'a reverse of the British'. It is ironic to consider that, in the sociologist Béatrice Pouligny's fieldwork on local attitudes to peace operations in countries including Haiti, Cambodia, $\mathrm{BiH}$ and Kosovo, 'problems of driving on the roads and accidents caused by international staff [my emphasis] generally came at the top of the list' (Pouligny 2006: 168), and that serious injuries caused by the poor driving of military vehicles were the single greatest source of resentment towards the foreign force expressed by Bosnian interpreters in this author's own research.

Like these military narratives, the missionary narratives studied by Jean and John Comaroff also customarily began with a travel phase, and one that focused on the narrating self rather than the context it was entering:

$[\mathrm{T}]$ he essential rite of passage into the African reality was the overland trek from the coast to the interior. As they edged away from the comforting civilities of the 
Cape Colony toward territory unknown, these latter-day crusaders sought a reference point for their grand visions on the 'empty' landscape. But what appeared to them as a featureless desert was, as we have seen, a country colored by a history of social conflict, one in which they were already cast in an equivocal role. Far from a slumbering wasteland awaiting their benign attentions, it was an arena fraught with struggle between colonial factions for control over indigenous resources, especially human capital. (Comaroff and Comaroff 1991: 173)

The Bosnia narratives too contained a passage from 'comforting civilities' to an interior along one mapped, known and secure path. Some interviewees, whose responses might last as long as fifteen or more uninterrupted minutes, produced this type of account without prompting. Where the author as interviewer had to ask more questions, she too became implicated in producing a narrative of travel and movement. Even though this questioning stemmed partly from an awareness of literature on travel to the Balkans and partly from a question guide adapted from previous military oral history projects at the IWM, the interviewer too becomes complicit in supporting the interviewee to constitute himself/herself as a traveler and in failing to challenge the silences of the first-person travel frame.

\section{On and off duty}

What did soldiers think they were in the Balkans to do? Those who contributed their memoirs to historical record by publishing books or taking part in this research project usually depicted their tours of duty in compassionate terms - the will to make a difference they were sometimes not allowed to make. One civilian language instructor, a Sarajevan woman living in the UK, described her military students in 1993 as motivated by a sense of activism with 
which she sympathized: 'they were eager to go there and to do something, you know, British government is not doing anything, but we want to go., ${ }^{13}$ The strongest frustration with political and command constraints on military agency is expressed in published memoirs from the period where strict rules of engagement prevented UNPROFOR from evacuating non-wounded civilians, most of all in the case of the British military interpreter Capt Miloš Stanković (the son of a Serbian royalist army officer) whose Army career came to an end when he was arrested, but never charged, on suspicion of passing information to Bosnian Serb forces (Stankovic 2000). Stanković writes scathingly, for instance, of a NATO air strike that affected his liaison relationship with Bosnian Serb forces: 'All this left us in a lousy position. Regardless of whether or not a strike had been justified, we'd sent quite contrary and conflicting signals to the Serbs. [...] From the Serb perspective we, the UN, had lied' (Stankovic 2000: 328).

Though no interviewee for this project was as bitter as Stanković, several suggested that western politicians, the US government or the UN hierarchy had impeded UNPROFOR's ability to protect. Louise, for instance, remarked in comments that seemed to apply both to $\mathrm{BiH}$ and the site of her next deployment, Rwanda (where she had witnessed the aftermath of machete attacks while interpreting for a field ambulance):

If they were outside a UN-designated vehicle or building, we were not allowed to engage anything or anyone. It's their war. Our rules of engagement said, if a spat starts off, people start fighting one another, they're hacking chunks out of one another with machetes or shooting each other, you are not allowed to intervene. It's not our war. Very frustrating. ${ }^{14}$

A member of the 1992 British reconnaissance party to central Bosnia included in his narrative the observation that: 
we couldn't get in through Serbia, because the war was too active, and the ethnic cleansers were presumably really too determined, and probably because our politicians could not seem to find a way forward in terms of being strong enough to negotiate, I mean, the western politicians generally. ${ }^{15}$

Those serving after Dayton appeared more comfortable with their mission's rationale, or at least did not narrate comments such as the above. The post-Dayton force was of a peace enforcement rather than peacekeeping nature, commanded by NATO instead of the UN, and Britain's high commitment to NATO (including regular exercises with other NATO militaries) had already won soldiers' confidence in the organization's effectiveness. Tony, the artillery officer who served shortly after Dayton, narrated the NATO force as more appropriate than what had gone before:

[Before December 1995] the British Army was involved with the UN, in a peacekeeping operation, and I think we didn't really deploy any heavy guns. My regiment had something called the AS-90, which was a self-propelled gun, which was probably heavier artillery than they had in theatre, and so once the Dayton Peace Agreement had been signed the rationale was to put a more warfightingtype army into the field, into Bosnia, to enforce peace. And therefore my regiment, being one of those types of regiments that would be deployed was then put on a readiness to move. ${ }^{16}$

As professionals - an important component of narrators' military identity - soldiers found satisfaction in improving socio-economic relations at the level where their actions and choices had immediate effects, the community near their base. Mark, a REME company 
commander, took an initiative to improve the local economy and promote social peace by hiring local mechanics and carpenters for the base's workshop. The employment process led him to learn in detail about blue-collar work in socialist Yugoslavia and confront the town's mayor (who attempted to monopolize employment for his associates) over the nature of political authority; as a symbol of the improvement in local prosperity, he gave the sudden availability of superior red wine (Vranac) from Montenegro in the town's shops. ${ }^{17}$ Besides core military tasks, soldiers dedicated themselves to work such as repairing or rebuilding community buildings (particularly those benefiting children), procuring inexpensive essential supplies for teachers, doctors and vulnerable inhabitants, and organizing enjoyable events especially football matches between foreign soldiers and local men. These were usually remembered as happy, satisfying occasions, although visits to medical facilities sometimes produced uncomfortable encounters between British and ex-Yugoslav norms of healthcare, e.g. concerning the treatment of children with learning disabilities. ${ }^{18}$ Once BiH had stabilized after Dayton, civil affairs officers could pump-prime enterprise projects that could be completed within a unit's six-month tour, cleaving closer to the official discourse of development and enabling local people to reconstruct the country themselves. Steve, a military colloquial speaker who served near Mrkonjić Grad in 1999, felt that the small tasks he was able to perform were the essence of the Army's mission:

SFOR, Stabilization Force, were there to help out people, to try and get the country back on its feet. And if that's sorting firewood for an old woman, it's a little step. If that's sorting out wood for that old woman, that's a little step. [...] Used to sort little problems like that out. I mean, they probably wouldn't change the world, but you're making people's lives better. By giving them wood-burning 
stoves, by clearing a classroom out full of pests. So the little things, really. Interesting work. $^{19}$

Short-term quick impact projects, however, have raised concerns on a structural level that which those who implement them are rarely in a position to perceive. Béatrice Pouligny has found that the funding of these projects may highlight to local actors that the intervening force is not in fact committing resources in proportion to its power:

more often than not those small projects do not go beyond superficial repairs to a road or the roof of a school or dispensary. These efforts are paltry in relation to both the needs and the means deployed at the same time for the missions themselves. Frequently such aid is also resented as an insulting penny in the hat, and as proof that much more can be done. (Pouligny 2006: 116)

One interpreter for British forces near Mrkonjić Grad, indeed, recalled taking the brunt of a schoolteacher's frustration with the force's unfulfilled promises when she interpreted between him and the third or fourth British unit to rotate into the area and visit the school:

They would ask, 'So what do you need?' For example, 'What do you need in this village?' And the headmaster would say, 'Well, OK, we need new desks, and [...] a blackboard in the school.' 'OK, we'll see what we can do. I can't promise anything, but we'll see what we can do.' That was, those two sentences, 'We cannot promise anything, but we'll see.' And, you know, four months later, six months later, you come and they say, 'So what do you need?' And the headmaster is like, 'I've said this before, but I know you can't promise anything, but you'll 
do your best, I know, I know.' And after some time you start to become - I was in

a few situations very embarrassed, because I felt it's my responsibility. ${ }^{20}$

Soldiers leaving $\mathrm{BiH}$ after a six-month tour did not have the opportunity to observe that, even though every military visitor to the school might have found personal satisfaction in his or her connection to it, the cumulative impact of repeated visits and commitments from representatives of a privileged armed force was not necessarily so welcome locally. The significance of individual and structural contribution existed on separate and often conflicting levels of experience.

What of the duty that set the military apart from even the best-resourced and bestprivileged foreign civilians, the duty to kill? Peacekeeping, as the literature acknowledges, values liaison and negotiation above warrior skills, threatening the soldierly identities of elite troops in particular (Winslow 2004: 9) but not exclusively (Kernic 1999: 122-23). Narratives from Bosnia by infantry and cavalry soldiers (the arms with highest expectations of directly fighting the enemy) are overshadowed by memories of not being able to take part in combat because the UN mandate prevented it or because the violence had already ended. The text that most resembles a first-hand memoir of war, with its emphasis on the gulf of understanding between those who have and have not experienced combat, is in fact by Anthony Loyd, who was no longer a serving soldier when he spent time in $\mathrm{BiH}$. His narrative nonetheless finds the most fulfillment at Stara Bila near Vitez, where he was in the company of a British battalion, and his non-combatant, non-witness Others include 'the post-conflict generation of journalists and NATO representatives in Sarajevo' (Loyd 1999: 5), 'quasiacademics who were never there', 'politicos' (Loyd 1999: 30), his own girlfriend in London, 'columnists who wrote about Bosnia without ever having been there' (Loyd 1999: 157), a sexually attractive female Red Cross worker who mocks his attempt to deheroicize his rescue of a child, and the survivor of a UK football stadium disaster who 'could not tell the 
difference between mass murder and accident' (Loyd 1999: 283). Loyd aligns himself with 'most of the other young Light Division officers' during his Army career who, he relates, were fascinated by foreign war as a means of testing their masculinity:

Some were even more vitriolic than me, and came right out with it: 'We want to know what killing is like.' The words hang in my mind. If you are a young man of combat age frustrated by the tedium and meaninglessness of life in twentiethcentury Europe, you may understand them. If not, you will probably think they come from a psychopath. (Loyd 1999: 67)

A similar sentiment emerges from Patrick Hennessey's memoir of Army service in the mid2000s, which contains an extremely brief account of a bored and detached six-month tour to the routinized Bosnia of several years after Dayton before acknowledging the excitement of combat in Afghanistan (Hennessey 2009). In this author's own study, infantry and cavalry were not as well represented as combat support and combat service support corps, in particular Army educators. The account closest to the Loyd/Hennessey junior officer experience belonged to Tony French, a captain in the Royal Horse Artillery who served in $\mathrm{BiH}$ in the early implementation phase of Dayton. His initial role as a forward observation officer put him conceptually 'at the front line identifying targets' but once it became clear artillery use would not be necessary he was given liaison responsibilities which he found significantly more boring, as his narrative imagined explaining to a replacement:

But to be honest from my perspective it was like... actually very dull now, and I would think, 'All you're going to be doing is rebuilding the local school.' Which, you know, fantastic, actually, and would give you an awful lot of sense of 
achievement, I think, to do something like that, rather than just... doing what I did, I think, was, near the end it was just deathly boring and quite sad, sad, completely. $^{21}$

The narratives collected by this author exhibited a marked silence when it came to the soldierly work of combat, and even more so of killing - although in terms of the narrators' own roles and in terms of their force's mission, combat was not what most of them had been sent to do.

For many soldiers - especially those bored by the realities of their duties in $\mathrm{BiH}$ - the most distinct memories of $\mathrm{BiH}$ lay in off-duty time, when they had the most freedom to experience the country (Tony, who engaged in frequent leisure travel after his role change, described himself as 'turning into a military tourist ${ }^{22}$ ). British soldiers were usually permitted to socialize in town and were allowed up to two cans of beer a day while off duty - unlike US troops whose stricter force protection regulations restricted them to base and to drinking nonalcoholic 'near beer' - and their accounts of off-base leisure thus often involved a semilicensed loosening of behavioral boundaries. A memoir by Monty Woolley, a cavalry lieutenant attached to The Cheshire Regiment in 1993, locates much of the action in Tuzla, where a small force spent quite some time away from the main base at Vitez. Woolley's account of Tuzla nightlife in the alluring but platonic company of two female interpreters culminates at a farewell party organized by one interpreter's father, the mayor. His selfdeprecating exaggeration of a junior officer's military masculinity (and vanity), having even playfully taken on some of the local military hypermasculinity, becomes a serious appreciation of genuine military values in comparison to the status-seeking civilian world: ${ }^{23}$ 
Having entered the club dressed in my issue combats, I had stripped off my winter layers down to a black polar-neck top that I often wore to annoy the squadron leader. Strategically strapped around my chest was the black leather shoulder holster I had bought from a local man in Vitez. In it was my loaded Browning $9 \mathrm{~mm}$ pistol. Needless to say I enjoyed this slightly surreal and certainly unique opportunity, even if I did look a pratt, and ensured the event was recorded on film. And that was what this was, just an opportunity for fun, not some sad childhood ambition to be the Milk Tray man, no certainly not, for at school I had had a pathological fear for the swimming-pool's top diving board!

At first I felt self-conscious because I knew what most were thinking, but knowing the chance was unlikely to arise again, I made the most of it. The next nightclub I was likely to patronize would be in London and not the sort where pistols are handed in at the door. The clubs that I frequented were in Fulham and typically the hunting-ground of city boys. They were easy to identify as they would arrive dressed in stripy suits carrying filo-faxes having continued from their offices to pubs then clubs; rather a sad highlight in the day of a young man. Nevertheless, as we UN soldiers slugged local bottled beer in Bosnia while swarming around only a handful of local women, they were in the same London clubs impressing girls with bottles of chilled Champagne and cocktails at exorbitant prices. They had GTIs and BMWs to drive girls back to their flats in; I had to share a Bedford truck with drunken soldiers then retire to a smelly sleeping bag. Nothing would have persuaded me to change places; this life, I believed, was much more fun. (Woolley 2004: 125) 
For Woolley, however, Tuzla was a false climax. After returning to Vitez, he would be part of the first group of British soldiers to attend the aftermath of the horrific massacre at Ahmići, where Bosnian Croat troops had destroyed a mixed village by burning Bosniak villagers alive.

Socializing with local women also appeared in some interviews as a source of danger. Tony, who had served in one of the RS's tensest areas, illustrated his paranoia about interpreters from that locale with an account of how he came to trust one interpreter after his fears about a trap proved unfounded: an interpreter had told him about a new pizzeria, 'but I was so suspicious I just thought it was a trap, I thought we were going to turn up and we were going to get slotted', therefore he came to the pizzeria in an armored vehicle. ${ }^{24}$ Another junior officer in a different unit had once slept with his radio turned in case a fellow officer, meeting a young attractive female kitchen hand after hours at the unit's civil affairs house, got into trouble and needed to request assistance. These anxieties should be set in a long context of sexual relations between foreign soldiers and local people being framed as a source of danger for the soldier: the training of male (but not female) SOE personnel, for instance, had included a simulation of seduction by female enemy agents to assess whether a man was at risk of revealing his real identity (Pattinson 2007: 72-3). Such fears still coexisted with what Cynthia Enloe (1990: 28) describes as a masculine touristic ideology based on the essentialization of local women as sexual objects: 'If the women are of a different culture, the male tourist feels he has entered a region where he can shed civilization's constraints, where he is freed from standards of behaviour imposed by respectable women back home.' For male soldiers at least, the tension between these ideologies contributed to the perceived excitement of temporary presence in a conflict zone.

In parallel to the exotic elements of leisure time in $\mathrm{BiH}$, off-duty experiences also reflected the mundane qualities of tourism in a non-English-speaking country where food, drink, consumer goods and services (including sex) were startlingly cheap. George had been able to 
buy cheap pirate CDs from a stall outside the gates of his base (although hindsight drawn from a later tour in Iraq, where he had been told insurgents used music and software piracy to fund their activities, now made him think differently about the practice). In Split, Louise and Geoffrey had both had to deal with the aftermath of incidents where drunken soldiers had come into contact with Croatian law enforcement. Geoffrey's avuncular account described the misbehavior of Croatian soldiers within British military space: he had reported four drunk soldiers in a stolen car to British military police, but:

the policeman rang up and he said - most disappointed - he said Croatian Army got there first, and we were there in time to see them all being led away in handcuffs (laughs). Croatian Army don't mess about, you know. Guilty as charged, come here! $!^{25}$

The prospects of a Briton receiving authority to exert discipline over foreign soldiers and of violence against these men by their own military police are both neutralized in this narrative by a humorous tone that frames it among one of many amusing incidents from Divulje Barracks. To think through the full implications of their arrest, which are instead displaced into the comment that the 'Croatian Army don't mess about', would undoubtedly have disrupted the narrator's preferred account of his service as 'what I call a Mediterranean holiday with pay' ${ }^{26}$ Louise, in contrast, came closer to filling the silence in her account (again framed as the narrative of an older and responsible female captain) of attending a reverse situation involving soldiers from an allied contingent:

I was driven by the RMP, the military police, I think a sergeant and a corporal, into Split. To the police headquarters. Where I had been on a number of occasions 
to talk with the Croatian chief of police, whom I didn't like but I had to woo, and he used to give me slivovitz at nine o'clock in the morning and I used to have to drink it. And he used to touch me on the thigh, and all that sort of business, all very unpleasant, but because I had to be a diplomat, and that was my role, I just had to grin and bear it, put up with it. [...]

What had happened was two Scandinavian soldiers, I forget whether they were Swedish, Swedish / Norwegian, had just deployed, realized how cheap the beer was. 'Cause you know Scandinavian countries are very expensive [places] to live, and alcohol is very expensive. Well, they went out and got absolutely drunk, stole a Croatian military police car, crashed it, badly. I saw it, I saw the wreck. Now they were both sitting there in front of me, their injuries were partly consistent with having been in a road traffic accident, and partly consistent with having had an absolutely thorough pasting from the Croatian military police. They had been battered to bloody pulps. They were incoherent. I know they were probably still drunk. I wanted to get them out, and I wanted to take care of them, take them back to the British camp, where we could find out where their unit was and get them collected, 'cause I wasn't sure they were going to last until the morning. And they wouldn't let me have them. That was an awkward G5 [civil-military cooperation] situation, which I couldn't win, all I could do was report it. ${ }^{27}$

The temporal setting of Louise's account (wartime 1993 not 1998) and her own physical presence after the arrest leaves no space for a humorous conclusion, yet illustrates the limited power of a foreign army captain serving as a liaison officer and interpreter vis-à-vis the coercive power of the host state. 
Boredom, in the eyes of base commanders and chaplains, was the enemy of discipline. Mark, an officer with a remarkable personal commitment to languages, had used ad hoc classes in the local language as a means of keeping soldiers occupied and preventing alcohol abuse. Bases that had been in place for several years also tended to acquire leisure facilities installed and left behind by various battlegroups, thus George remembered his base had had a gym and even a sauna in a building with a beach mural on the lobby wall: "everybody liked to say, you know, go down to the beach, get massive. ${ }^{28}$ For George, however, travel imposed obligations as well as pleasures. George (like Mark, his former commanding officer) frequently commented on the importance of Britons learning foreign languages. His explanation segued from the example of friendly military patrols in an Arabic-speaking country to the image of monolingual British holidaymakers in Spain, from the standpoint that a small amount of linguistic knowledge could serve as credible proof of good intentions:

I still believe, I suppose altruistically, that we are as an army a force for good, we're trying to do the right thing for people. It may not always come across that way, but I still firmly believe that the best thing we can do is, when we're in a country somewhere, is, you know, take your helmet off, take your sunglasses off, take your glove off and go and shake somebody by the hand. Whether it's, you know, waving at us on the street, going 'Salaam aleikum,' or when they say that to you, 'Aleikum salaam.' [...] [I]t doesn't really matter whether you're an occupying force, whether you're a peacekeeping force, or actually whether you're on holiday, in somebody's country. I mean, you look at the service you get if you go to Spain on holiday, and you can actually sort of ask for a few things in Spanish, they think it's fantastic. Whereas if you go 'Egg and chips mate', you 
know... you get the same old stuff thrown on your plate, and it's probably been recycled from the bin. ${ }^{29}$

\section{Going home}

Soldiers deployed with their unit typically spent six months in $\mathrm{BiH}$, traveling and returning as a group - the British Army's standard, expected model of operational deployment. The system differed for individuals who deployed on attachment to a different unit, such as officers who came forward for headquarters posts, non-Army personnel gaining operational experience as civil affairs or press officers with Army units, and military colloquial speakers and interpreters. Most of these also served six-month tours but arrived and departed at different times from their hosts. The most highly skilled military interpreters, perhaps the scarcest resource of all, often found themselves serving much longer than six months. The interpreters Miloš Stanković, Nick Ilić and Nick Stansfield all spent a year or more in UNPROFOR, and several years later a half-Serbian Territorial Army Engineers officer was mobilized from mid-2000 to mid-2002 (comprising bomb disposal roles at two headquarters, refresher language training and a military interpreter tour) with only a six-or seven-month break.

A 'handover takeover' of approximately ten days required public-facing officers to pass on their experiences, tips and contacts; military interpreters, similarly, might advise their relief of important vocabulary for the job that Army language training had not covered. Units had to pack up equipment they had brought into 'theatre' so that it could be shipped back to Britain (or Germany), ensure the good condition of equipment that belonged permanently to the British military formation in the area, and audit their stores and accounts. Soldiers who had completed their individual handovers remained at a loose end until it was their turn to 
join a transport home. New liaison officers would still take time to rebuild interpersonal relationships with their contacts. Local interpreters who had worked at one base for several years frequently mentioned in their own interviews that incoming officers would almost without fail ask them for advice about the local area or the best negotiating strategies to use with local officials.

Troop rotation caused some difficulties for Bosnian officials who suddenly encountered new post-holders every six months, for enthusiastic liaison officers who felt they could have had more impact by staying in post, and for permanent civilian supervisors in some offices who could not easily follow up allegations against local civilian employees. However, in the fast-changing Bosnian political environment it allowed tired soldiers to be replaced by fresh personnel whose expectations would not be based on previous hostile and threatening encounters. Tony's experience in a tense Serb-controlled area shortly after Dayton hinted at one reason why rotation was necessary:

I think if I had been asked to stay and help rebuild, I just - I couldn't have done that. I would have found it very difficult to motivate me and my soldiers. Who, you know ... had been shot at, and all kinds of stuff. ${ }^{30}$

Rotation also guarded against the risk of liaison officers becoming over-close to their opposite numbers, and made what the military saw as an acceptable compromise between operations and family life. A formed unit leaving theatre could look forward to a period of unofficial or official 'decompression' and debriefing, and a brief resumption of family life while on leave, before coming back to prepare for the unit's next exercise or deployment. Attached personnel, on the other hand, very often felt that they had missed out by finishing their tours as individuals. Miloš Stanković (2000: 205) wrote that he had only had five days 
between leaving $\mathrm{BiH}$ in November 1993 and starting a two-year staff tour of Northern Ireland: although this contravened the mandatory three weeks' leave, he felt that 'a single capbadge individual' on attachment would always fall through the cracks. Individual attachments in this study felt similarly. Louise explained that members of a formed unit underwent 'an enforced period of self-debriefing' between the end of a deployment and their individual leave, yet she had left halfway through her host battalion's tour. She had missed serving with people she already knew and was also left unable to take part in the expected military practice of remembering the deployment with friends who had also been there, meaning that the attachment system had effectively shattered the regimental foundation on which the British Army was normatively based. ${ }^{31}$

Ten to fifteen years, in most cases, had elapsed between the interview narrators leaving $\mathrm{BiH}$ and their producing a narrative of linguistic/cultural contact and travel. The passage of time, and exposure to news of what had become of BiH's constitutional settlement (no further armed conflict, yet continued suspicion between the two entities), did not always facilitate a composed perspective on the value of the force's mission in BiH. When interviewed in 2010, George's reflections on the length and nature of Britain's deployment were still divided:

We were there really to help them stand on their own two feet, and what we ended up being is we ended up being more like a welfare agency that kind of perpetuated the problems for a little bit. I don't... it's a very very harsh sort of generalised judgement. I know there was a lot of good work going on in different areas, but I think if we'd have managed to pull ourselves away from there sooner, that may have actually enabled the Bosnians, or forced them, more appropriately, to kind of stand on their own two feet, but at the same time recognising that there is a huge amount of suppressed ethnic tensions in that particular area. You know, 
maybe we had to stay for as long as we did, and, you know, with the Kosovo thing as well. ${ }^{32}$

Framed this way, the account cannot reconcile concerns about the international community's long-term effects with an understanding of $\mathrm{BiH}$ as a place where ethnic demography poses a continued risk of violence that would require and justify an extended foreign military presence.

\section{Conclusion}

The title of this paper comes from a provocative question posed by one of more than twenty interpreters from former Yugoslavia who contributed interviews to Languages at War. Jovana had been studying mathematics and computing in Belgrade before she was offered an interpreting job with British forces at Mrkonjić Grad (in which capacity she met the headmaster in the extract above). She enjoyed making friends with her shiftmates and learning details of regional British cultures and accents but became upset with the superior attitude towards Bosnian society on the part of soldiers who believed that BiH's disadvantages stemmed from endemic backwardness rather than the consequences of a devastating war. Ultimately, she questioned whether foreigners who had failed to broaden their experiences beyond the insulated and familiar context of their own military base could even claim to have 'been in Bosnia' at all:

So I think it's just a lack of education, information, and that kind of ignorant attitude, 'we are better.' 'Oh! I've been in Bosnia!' 'Oh, where've you been [for] six months in Bosnia?' It's all just, 'Oh, I had two tours in Bosnia.' 'So where’ve 
you been?' 'Oh, in Mrkonjić Grad.' 'Have you ever left a camp apart [from] going on patrol? Have you ever been, you know?' 'No.' [...] [S]o, 'You know Mrkonjić Grad area? You don't even know Bosnia? And you're telling me that you were, you know, in Bosnia?' It's just, I think that's, not being educated, not being informed. ${ }^{33}$

Interpreters were natives of the country where British soldiers traveled (if not originally from $\mathrm{BiH}$ then certainly from Yugoslavia), and continuously employed in places where Britons spent only six months at a time. Their own accounts of working with the British necessarily introduced different dimensions of the job, from the in-jokes they as native speakers could work into OPTAG training to the boredom and frustration that could eventually arise from revisiting the same organization with different liaison officers and making the same promises to the same authority figure. The worst drivers they encountered were irresponsible young Britons. Interpreters, more than the British, remarked on the strangeness of soldiers splitting 'home' between the UK and Germany (the site of many units' peacetime bases, where many soldiers had children and wives). The job of building and enforcing peace in $\mathrm{BiH}$ played a much more prominent role in interpreters' life stories than it did for most British soldiers, and was inseparable, of course, from the war's consequences for their own selves, societies and families.

Every oral history is necessarily partial, grounded in a specific location and time and structured by the narrator's role, personality, preconceptions and hindsight. The subjectivity of a junior officer from London, an engineer from Scotland or a student from Belgrade will necessarily affect what a person chooses to remember and tell, just as the subjectivity of a young civilian academic from south-east England will have affected what the author as a researcher has chosen to ask and write. The interviews collected for Languages at War 
necessarily included narratives, prompted by the interviewer, of pre-deployment language briefings and on- and off-duty experiences of working with interpreters; languages were marginal in another oral history project (on British forces at Goražde) by the late journalist Gillian Sandford (GMS Media 2001), though this collection too produced a composite travel narrative with tropes of arrival, service and departure. The precedents of travel writing and tourist expectations continue to structure new narratives of travel to the Balkans, even though an oral history interview will usually produce them through layers of retellings and responses rather than an uninterrupted linear narrative.

Many unthinking soldiers had to be shocked into marveling at the level of development in $\mathrm{BiH}$, though others - and not only graduate linguists - strove to find out more about the country, ask about puzzling observations from patrols and build on whatever amount of the local language they had been able to learn. The participants in an oral history project about languages and peacekeeping would naturally tend to fall into the second group. While disproportionately representing certain branches of the Army, particularly the former Royal Army Educational Corps, this collection is of significance to understanding the military precisely because it represents a diversity of military occupations beyond the combat arms, the focal points of published memoir. Juliette Pattinson (2007: 5) has recognized the limitations of published autobiographies in a SOE context: publishers have favored dramatic action and conformity to existing narrative conventions, while women rarely represent themselves. The privileged perspectives in British military travel memoirs of $\mathrm{BiH}$ are those of the commanding officer (Stewart 1993; Rose 1998; Barry 2008) and of the junior infantry or cavalry officer as would-be combatant (Woolley 2004; Hennessey 2009) or as witness (Loyd 1999; Stankovic 2000), reflecting the subjectivity of a particular age cohort and gender. The narratives of soldiers in combat support and combat service support arms, still conceptualized 
as behind-the-lines corps whose experiences do not lend themselves well to publishable drama, may help to broaden popular memory and understanding of what soldiering involves.

The constraints and legacies of existing models of travel narrative nonetheless permeate even narratives of growing in linguistic and cultural competence through travel. This is at its most evident in the trope of entry to theatre, which follows conventions of narrating British travel-on-a-mission that date back to at least the 19th century, and in the scene-setting introductions or conclusions with which military narrators explain the conflict. The course of entry narratives is strikingly similar to the Comaroffs', with coastal enclaves still existing as a leisure site to which one may temporarily return during the stay and through which one will exit - although the narratives may be complicated and unsettled by disturbance and violence within the coastal site itself. The traveled landscape, if not quite empty, is still seen as completely devastated, with an emphasis on destruction and complete atomization rather than on what social structures exist, and with two linked simplified assumptions: (a) that conflict is a natural result of ethnic difference in this region; (b) that ethnic difference, rather than proximate political and criminal acts by identifiable individuals, explains the conflict. The short tours, familiarized base environments and regulated contacts with local society appear to prevent soldiers from perceiving the strategies, negotiations and compromises that emerge from ethnographic narratives by anthropologists committed to long and repeated stays in local neighborhoods (a practice that the idea of stationing liaison officers in so-called 'LOT houses' within town centers appears to mimic). ${ }^{34}$ The acquisition of such a gaze depended on long stays of an indefinite duration, in conditions of shared risks and shared lacks of privilege, and on a relationship of trust that a declared and uniformed representative of a foreign armed force would rarely, if ever, be able to achieve. One pessimistic conclusion would therefore be to view any soldier's attempt to gain understanding as fundamentally inadequate. Another, slightly more heartening, resolution is to welcome rather than dismiss these efforts while 
recognizing that they are constrained and sometimes even invalidated by the structure, character and aims of the military institution today.

References

Bakić-Hayden, Milica, and Robert M Hayden. 1992. "Orientalist Variations on the Theme 'Balkans': Symbolic Geography in Recent Yugoslav Cultural Politics.” Slavic Review 51, no. 1: $1-15$.

Barry, Ben. 2008. A Cold War: Front Line Operations in Bosnia 1995-1996. Stroud: Spellmount.

Bougarel, Xavier, Elissa Helms and Ger Duijzings (eds). 2007. The New Bosnian Mosaic: Identities, Memories and Moral Claims in a Post-War Society. Aldershot: Ashgate.

Bracewell, Wendy, and Alex Drace-Francis (eds). 2008. Under Eastern Eyes: a Comparative Introduction to East European Travel Writing on Europe. Budapest and New York: Central European University Press.

Chalmers, Douglas M. 2001. Faction Liaison Teams: a Peacekeeping Multiplier. Fort Leavenworth: School of Advanced Military Studies.

Kimberley Coles. 2007. Democratic Designs: International Intervention and Electoral Practices in Postwar Bosnia-Herzegovina. Ann Arbor, MI: University of Michigan Press. Comaroff, Jean, and John Comaroff. 1991. Of Revelation and Revolution, vol. 1: Christianity, Colonialism and Consciousness in South Africa. Chicago: University of Chicago Press. Comaroff, Jean, and John Comaroff. 1997. Of Revelation and Revolution, vol. 2: The Dialectics of Modernity on a South African Frontier. Chicago: University of Chicago Press 
Duncanson, Claire. 2009. 'Forces for Good?: Narratives of Military Masculinity in

Peacekeeping Operations.' International Feminist Journal of Politics, 11, no. 1: 63-80. doi:

$10.1080 / 14616740802567808$

Cynthia Enloe. 1990. Bananas, Beaches and Bases: Making Feminist Sense of International Politics. Berkeley, CA: University of California Press.

GMS Media. 2001. Goražde: the Peacekeepers’ Tale. Double CD. [London?]: GMS Media. Hammond, Andrew. 2007. The Debated Lands: British and American Representations of the Balkans. Cardiff: University of Wales Press.

Hennessey, Patrick. 2009. The Junior Officers' Reading Club: Killing Time and Fighting Wars. London: Allen Lane.

Jansen, Stef. 2006. 'The Privatisation of Home and Hope: Return, Reforms and the Foreign Intervention in Bosnia-Herzegovina.' Dialectical Anthropology, 30: 177-99. doi: $10.1007 / \mathrm{s} 10624-007-9005-\mathrm{x}$

Kernic, Franz. 1999. 'The Soldier and the Task: Austria's Experience of Preparing Peacekeepers.' International Peacekeeping, 6, no. 3: 113-28. doi: $10.1080 / 13533319908413788$

Loyd, Anthony. 1999. My War Gone By, I Miss it So. New York: Atlantic Monthly Press. Pattinson, Juliette. 2007. Behind Enemy Lines: Gender, Passing and the Special Operations Executive in the Second World War. Manchester and New York: Manchester University Press. Pouligny, Béatrice. 2006. Peace Operations Seen from Below: UN Missions and Local People. London: Hurst.

Pratt, Mary Louise. 1985. 'Scratches on the Face of the Country: Or, What Mr. Barrow Saw in the Land of the Bushmen.' Critical Inquiry 12, no. 1: 119-43.

Rose, Michael. 1998. Fighting for Peace: Bosnia 1994. London: Harvill. 
Royal Welch Fusiliers. 1995. White Dragon: the Royal Welch Fusiliers in Bosnia. Wrexham: Royal Welch Fusiliers.

Rubinstein, Robert A. 2008. Peacekeeping under Fire: Culture and Intervention. Boulder, CO: Paradigm Press.

Simms, Brendan. 2002. Unfinest Hour: Britain and the Destruction of Bosnia.

Harmondsworth: Penguin.

Spence, Cameron. 1999. All Necessary Measures. London: Penguin.

Stankovic, Milos. 2000. Trusted Mole: a Soldier's Journey into Bosnia's Heart of Darkness.

London: HarperCollins.

Stewart, Bob. 1993. Broken Lives: a Personal View of the Bosnian Conflict. London:

HarperCollins.

Summerfield, Penny. 1998. Reconstructing Women's Wartime Lives: Discourse and Subjectivity in Oral Histories of the Second World War. Manchester and New York: Manchester University Press.

Todorova, Maria. 1997. Imagining the Balkans. Oxford: Oxford University Press.

Venuti, Lawrence. 1998. The Scandals of Translation: Towards an Ethics of Difference. London and New York: Routledge.

Winslow, Donna. 2004. 'Misplaced Loyalties: the Role of Military Culture in the Breakdown of Discipline in Two Peace Operations.' Journal of Military and Strategic Studies, 6, no. 3: $1-19$.

Woolley, Monty. 2004. Cleanse their Souls: Peace-Keeping in Bosnia's Civil War 19921993. Barnsley: Pen and Sword.

\footnotetext{
${ }^{1}$ Other interviewees have included local interpreters, peacekeepers from Denmark, professional linguists and civilian language teachers.

${ }^{2}$ See, e.g., Summerfield 1998.
} 
${ }^{3}$ See, e.g. Venuti 1998.

${ }^{4}$ Interview, February 2009.

${ }^{5}$ Interview, June 2009.

${ }^{6}$ Interview with member of the reconnaissance party, September 2009.

${ }^{7}$ Interview, June 2009.

${ }^{8}$ Interview, April 2010.

${ }^{9}$ Interview, February 2009.

${ }^{10}$ Interview, April 2010.

${ }^{11}$ Interview, February 2009.

${ }^{12}$ Interview, January 2010.

${ }^{13}$ Interview, April 2009.

${ }^{14}$ Interview, February 2009.

15 Interview, September 2009.

${ }^{16}$ Interview, June 2009.

${ }^{17}$ Interview, November 2009.

${ }^{18}$ An Army doctor interviewed by the IWM in 1996 (IWM Sound Archive 16966)

expounded at some length on local practices of prescribing strong sedatives for mental illness, which he associated with Communist regimes' treatment of dissidents.

${ }^{19}$ Interview, July 2009.

${ }^{20}$ Interview, November 2009.

${ }^{21}$ Interview, June 2009.

${ }^{22}$ Interview, June 2009.

${ }^{23}$ See Duncanson 2009: 72-3.

${ }^{24}$ Interview, June 2009.

${ }^{25}$ Interview, April 2010. 
${ }^{26}$ Interview, April 2010.

${ }^{27}$ Interview, February 2009.

${ }^{28}$ Interview, January 2010.

${ }^{29}$ Interview, January 2010.

${ }^{30}$ Interview, June 2009.

${ }^{31}$ Interview, February 2009.

${ }^{32}$ Interview, January 2010.

${ }^{33}$ Interview, November 2009.

${ }^{34}$ See, e.g., Jansen 2006; Coles 2007; Bougarel, Helms and Duijzings (eds) 2007. 